\title{
Property Ownership and Transferring Are Important Features of Your Farm Succession Plan
}

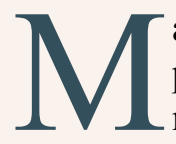

any people think an estate plan is just a will, but it is much more than that. Your estate plan will typically include documents and tools to distribute your property according to your wishes following your death. When it comes to transitioning your farm or any family business to the next generation, how property is owned and the property transfers prior to your death can be important features of your succession plan or estate plan. Titling property in a joint tenancy with rights of survivorship allows you to choose who inherits upon your death and to transfer the property outside the will. Transferring property, such as through gifting, allows property to go to the next generation prior to your death and provides control over who gets your property.
You Can Own Two Forms of Property: Real vs. Personal Property

In the law, title has a specific definition and means the legal evidence of a person's ownership rights in property (Black's Law Dictionary). There are two forms of property:

- Real property is land and anything growing on, attached to, or erected on it. For example, your farmland, crops growing on the farmland, and any barns and other structures on the farmland are considered real property.

- Personal property is a movable or intangible object subject to ownership and not classified as real property. Personal property includes, for example, farm equipment, tools, or company stock.

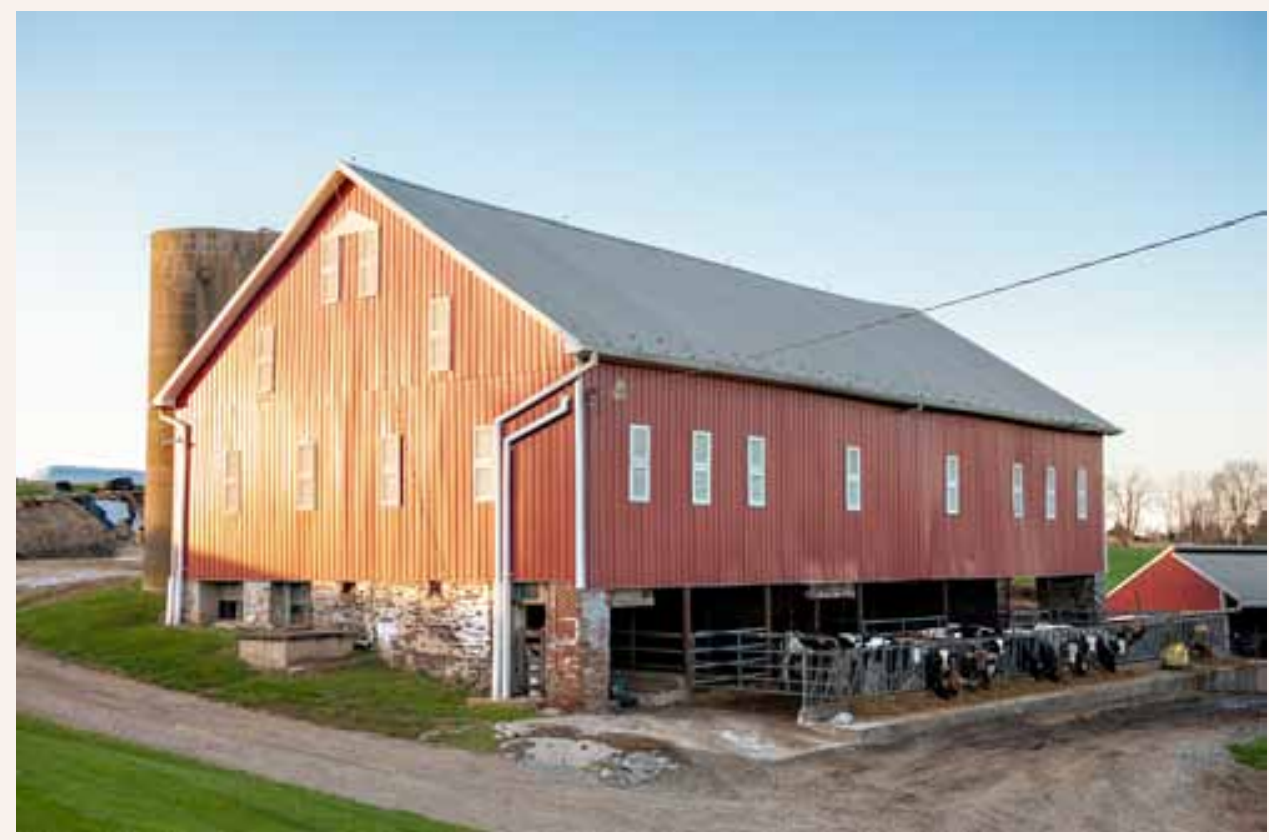




\section{How Do You Own Your Property?}

Fee Simple: Fee simple ownership, or fee simple absolute, is commonly the way property is owned, and can be useful in the estate planning process. The owner has the greatest possible control over the property, including the ability to dispose of (sell, gift, or leave in a will) the property at any time. The government through taxation, police power, eminent domain, or reverting ownership to the state with no heirs (also called escheat) can limit fee simple ownership.

Life Estate: A life estate is a possessive right in property. In a life estate, an interest in property is transferred to another person (life tenant) for the duration of a life. Because it lasts only a lifetime and cannot be passed on in a will, a life estate is more limited than fee simple ownership. For example, Brandon's mom deeded Brandon the farmland as a life estate for Brandon's life (Brandon is the life tenant). Usually, at the tenant's death, the property goes to a remainderman, the person who takes ownership of the property at death. Looking back at the previous example, Brandon's mom creates a remainderman in Jennifer, Brandon's daughter. Upon Brandon's death, the property passes to his daughter. The life tenant's interest in the property passes to the remainderman outside of the probate process.

Forms of Co-Ownership: Co-ownership is where more than one person owns a piece of property. Not all forms of co-ownership are equal, and each will impact your estate plan. Both co-owners will have access to the property and may not exclude each other. Co-owners can demand an accounting of profits from the property, such as from co-tenants for improvements made to the property, rents paid to a co-tenant, or profits received by a co-tenant. Co-owners also must contribute to the costs of owning the property (such as paying taxes and other costs). The forms of co-ownership are 1) tenancy in common, 2) joint tenancy, and 3) tenancy by the entirety.

Tenancy in Common: A tenancy in common requires two or more owners called tenants in common. Each tenant in common holds an undivided interest, meaning they own a part of the total value of the property with equal access to the property. The undivided interest of each tenant in common may be unequal. For example, Stacy and Sarah are tenants in common to Blackacre Farm, and each holds an undivided interest, but Stacy owns a 60-percent interest in the property while Sarah owns a 40-percent interest.
Co-ownership is where more than one person owns a piece of property. Not all forms of co-ownership are equal, and each will impact your estate plan.

Tenants in common can sell, give away, or transfer their interest to any person (including another co-tenant). Tenants in common hold no right of survivorship; when one co-tenant dies, his/her interest passes to his/her heirs, either by will or by intestate succession.

A tenancy in common is typically created through language such as "to A and B." The language creating the interest is important. Seeking a partition of the property through a court can end a tenancy in common. Under such a partition, the property is divided up among the co-owners based on their ownership interests. From our previous example, Stacy would end up with 60 percent of Blackacre Farm and Sarah, 40 percent. If a partition of the property is not possible, then the court may require a forced sale.

Joint Tenancy: A joint tenancy is a form of coownership where the co-owners (called joint tenants) have an undivided interest in the property and a right of survivorship. A right of survivorship means that when one joint tenant dies, any surviving joint tenant automatically acquires the interest of the deceased joint tenant. This form of co-ownership is common with

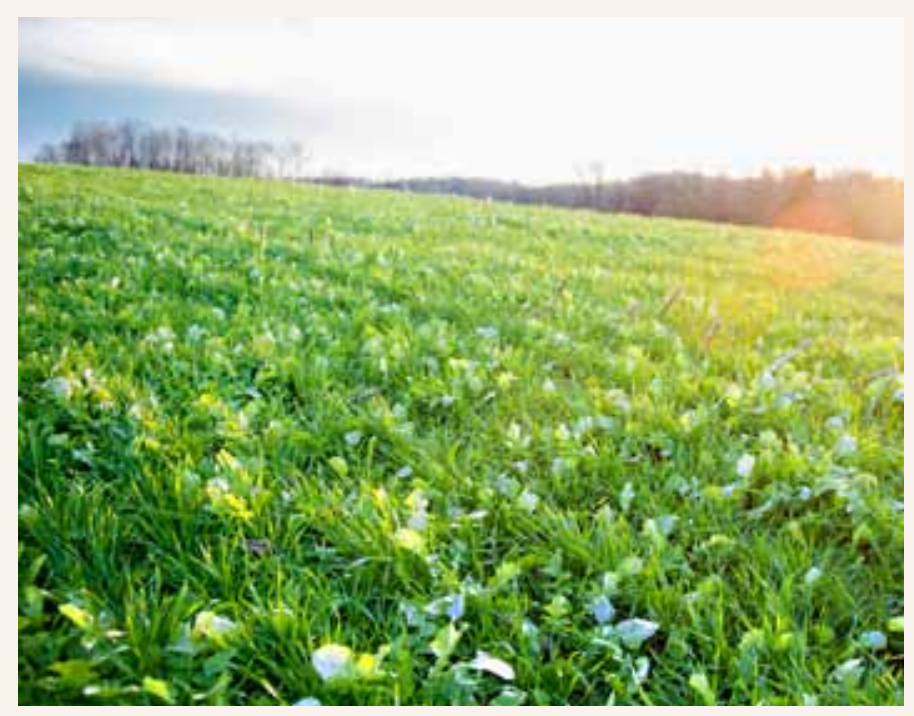

A joint tenancy is a form of co-ownership where the coowners (called joint tenants) have an undivided interest in the property and a right of survivorship. 


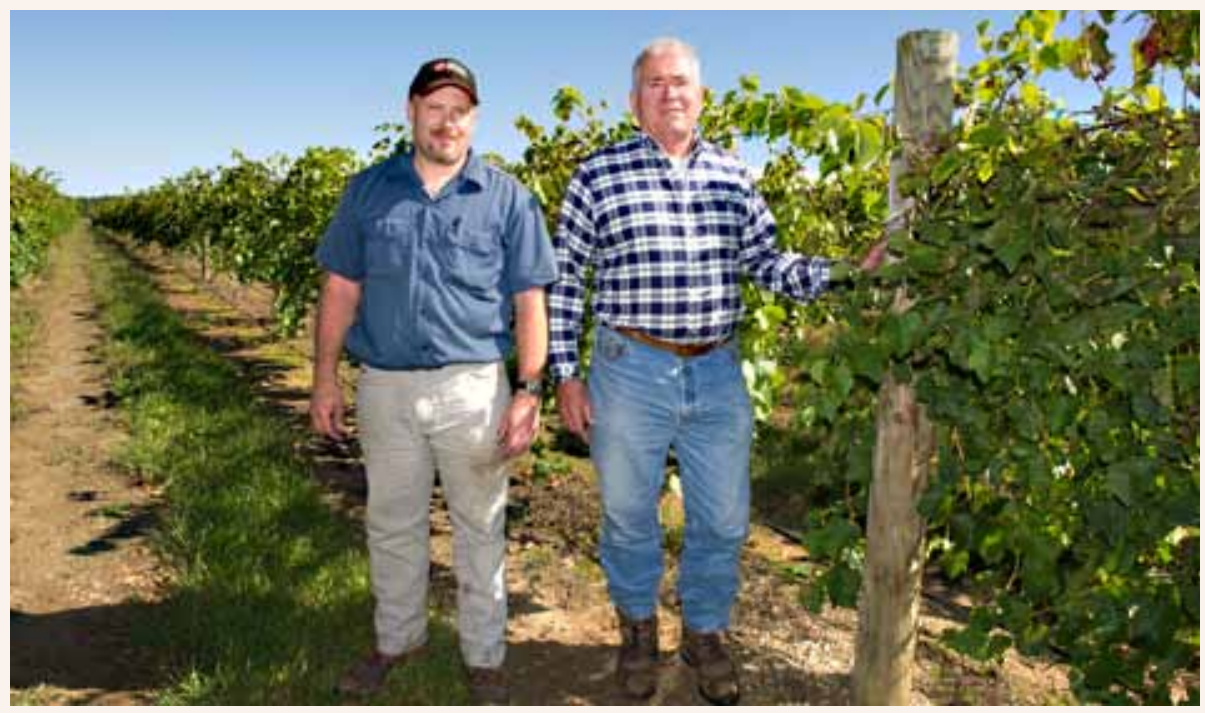

Gifting property is one way to transfer property prior to your death, and gifts come in two kinds: lifetime and deathbed.

property owned by a husband and wife, in states without tenancy by the entirety, or a parent and child.

This property interest will pass to the surviving co-owners outside the probate process and regardless of the terms of a will. For example, a father and son own a farm in joint tenancy. The son unexpectedly dies first and leaves his entire estate to his wife in his will. The farm owned in joint tenancy would pass to the father regardless of what the son's will says because of the right of survivorship. The father would now own the farm in fee simple ownership and would indicate in his will who inherits the farm upon his death.

This form of co-ownership is common with property owned by spouses (in states where tenancy by the entirety is not available; more on this in the next section) or a parent and child. To form a joint tenancy, the language needs to be clear, such as "to $\mathrm{A}$ and $\mathrm{B}$ as joint tenants with a right of survivorship and not as tenants in common."
As with a tenancy in common, seeking a partition of the property through a court can end a joint tenancy. If the partition is not possible, then the court could potentially require the owners to sell the property.

In Maryland, all property held by a married couple is presumed to be held in a tenancy by the entirety.

Tenancy by the Entirety: A tenancy by the entirety is similar to a joint tenancy but can only be created by spouses. Spouses would each own an undivided interest in the property and have the right of survivorship. If the parties divorce, a tenancy by the entirety would terminate.

In Maryland, all property held by a married couple is presumed to be held in a tenancy by the entirety. This presumption can be overcome by including language to create a joint tenancy or tenancy in common. Spouses may consider doing this for estate planning reasons.

\section{Transferring Property Is Commonly Done Through Gifts and Sales}

Another strategy in succession planning and estate planning is transferring assets, frequently through gifts and sales. In developing your farm succession and estate plans, work with your tax and legal professionals to choose the method which will work for your situation.

\section{Gifts Can Reduce the Size and Costs of Your Estate}

A gift is a voluntary transfer of property (personal or real) from the donor or grantor to another party, called a donee or grantee, without anything in return. For example, you decide to give $\$ 100$ to each of your children. If you do this and expect nothing in return, then the $\$ 100$ would be an example of a gift.

Gifting property is one way to transfer property prior to your death. Gifts come in two kinds: 1) lifetime and 2) deathbed. A lifetime gift is one made during the grantor or donor's lifetime. Giving your children $\$ 100$ during your lifetime would be a lifetime gift. A lifetime gift can also be for a future interest in property, such as promising your daughter shares in the family farm business upon her 30th birthday. This is an example of a future interest. A lifetime gift allows you to reduce the size of your estate, decrease administrative costs in your estate plan, and potentially lower estate and inheritance taxes upon your death. 
A deathbed gift is a gift given in anticipation of the donor's imminent death. For example, Parent A is suffering from a terminal disease and in anticipation of death, gives his children his entire estate. In order for this to be a deathbed gift, Parent A would have to die from the disease. If Parent A does not die, it would not be a deathbed gift, and is revocable.

Every person is allowed to gift to any individual tax-free up to $\$ 14,000$ a year in 2016 ; check with the Internal Revenue Service (IRS) to determine the tax exemption in future years. A couple can give up to $\$ 28,000$ a year in 2016 . Any amount in gifts exceeding $\$ 14,000$ a year to any particular individual is taxed at the federal rate of $40 \%$.

Individuals can use part of their Unified Credit to cover taxes due on gifts exceeding $\$ 14,000$, or $\$ 28,000$ per couple. The Unified Credit is a tax credit given to every U.S. citizen and resident to use against wealth transfer taxes for either taxable gifts or estate bequests. In 2016, the Unified Credit exempts a total of $\$ 5,450,000$ in cumulative lifetime gifts and estate transfers; it is adjusted each year based on inflation. For a married couple, the Unified Credit would exempt a total of $\$ 10,900,000$ in lifetime gifts and estate transfers. If a person uses this tax today to avoid taxation on his/ her gifts, it decreases the amount available at the time of death. Discuss with your tax professionals how best to utilize the Unified Credit to transfer property.

\section{Sales Are the Simplest Way to Transfer Property to a Loved One}

Another option is to sell the property to the person you want to have it. You will lose control of the

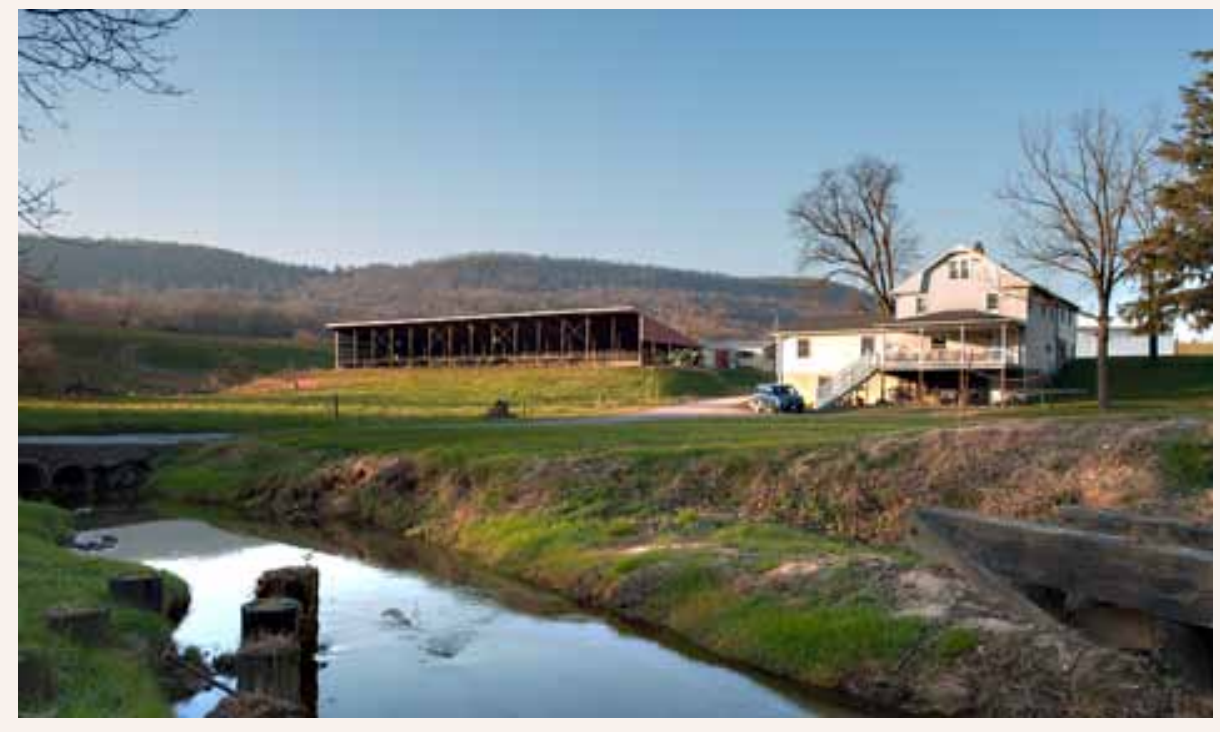

property but potentially gain capital for retirement or other advantages.

\section{In 2016, the Unified Credit}

exempts a total of $\$ 5,450,000$

\section{in cumulative lifetime gifts}

\section{and estate transfers.}

You can sell the property for cash or on credit. Depending on the terms of sale, if you sell the property on credit, you may receive cash payments over several years. If the buyer falls behind in payments, you may have the option to foreclose on the buyer, or take possession of the property again. You may also condition the sale with a contract for deed. In this case, the seller retains possession of the deed until certain conditions are met. For example, you could condition the sale of farmland to a child on your receiving two-thirds of the sales price before the child gets the deed. Once the child has paid two-thirds of the sales price, you would deliver title to the property.

Before selling any property, talk to your tax professional. Sales of property can have income tax implications and your tax professional can help structure the sale in a way to lessen your tax burden.

\section{Rely on Estate Planning Professionals to Help You Choose the Best Strategy to Transfer Your Property}

Transitioning your property and the farm to the next generation is not a simple process. How property is owned impacts how it can be transferred upon your death. It's important to check deeds and titles to see how co-owned property is held. This information will help farm transition and estate planning professionals as they work with you to develop a plan to transition the farm to the next generation.

Transferring your property to another party through gifts or sales will also facilitate the transition to the next generation. Each strategy can have tax implications and could be used by your team of professionals in the transition plan or estate plan. Work with your professionals to make sure you 
choose the gifting or sales strategy best for your situation.

Finally, remember that just because your neighbors are utilizing one strategy to pass on the family farm, it may not be the best strategy for your situation. Listen to the advice of farm transition and estate planning professionals to make sure you have a plan that works for you and your family.

\section{Glossary}

Eminent Domain: the right of the government (federal, state, or local) or private person/corporation authorized to take private property for a public use, paying just compensation for the property taken.

Life Tenant: owner of the life estate.

Partition of the Property: process utilized by courts to divide up a concurrent estate (such as tenancy in common or joint tenancy) into separate portions representing each owner's interest.

Personal Property: movable or intangible object subject to ownership and not classified as real property.

Probate: legal process where a will is proven valid, accepted as a public document, and is the last testament of the deceased individual.

Real Property: land and anything growing on, attached to, or erected on it.

Remainderman: person who is entitled to property upon the termination of the life tenant's life estate.

Right of Survivorship: when one joint tenant dies, any surviving joint tenant automatically acquires the interest of the deceased joint tenant.

\section{References}

Lynch, Lori, Paul Goeringer, and Wes Musser. Estate Planning for Farm Families. University of Maryland, College Park: Extension Fact Sheet No. 972 (2014).

Tengel, Patricia. Estate Planning - Owning and Transferring Property. University of Maryland, College Park: Extension Fact Sheet No. 410 (1997).

The Agriculture Law Education Initiative (ALEI) is a collaboration of the University of Maryland Francis King Carey School of Law at the University of Maryland, Baltimore (UMB); the College of Agriculture \& Natural Resources at the University of Maryland, College Park (UMCP); and the School of Agricultural and Natural Sciences at the University of Maryland Eastern Shore (UMES). ALEI is an initiative of the University of Maryland: MPowering the State, a strategic alliance between UMB and UMCP created in 2012 to significantly expand research, business development, and student opportunities at both universities.

\section{Authored by:}

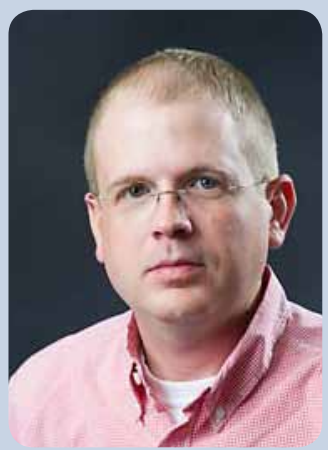

Paul Goeringer Extension Legal Specialist lgoering@umd.edu @aglawPaul

University of Maryland College of Agriculture and Natural Resources

Department of Agricultural and Resource Economics Symons Hall, Room 2119 College Park, MD 20742 (301) 405-1293 www.umaglaw.org

Twitter: @MDAgLaw

Photos: Edwin Remsberg Design: Kerry Design \& Illustration 